\title{
КІТЧ В МУЗИЦІ (РЕЦЕПЦІЯ ДОСВІДУ І ДІЙСНОСТІ)
}

\begin{abstract}
Метою статті $\epsilon$ аналіз явища кітчу в музиці з виокремленням рецептивного характеру суб'єктивного досвіду індивіда в умовах його об'єктивації дійсності. Методологія дослідження спирається на феноменологічний метод для об'єктивного вивчення проблеми кітчу в музиці, що окреслена суб'єктивним досвідом у сприйнятті, судженні та почутті, та герменевтичний метод, який складає основу пояснень явища кітчу в музиці як відтворення творчих процесів у зовнішніх проявах. Наукова новизна полягає в новому ракурсі дослідження явища кітчу не в притаманних йому зображальних формах мистецтва, а в музиці, та осмислення мистецької цінності кітчу в музиці крізь призму суб'єктивного досвіду індивіда та його об'єктивації дійсності. Висновки. Осмислено явище кітчу та його рецептивний характер з музичним жанром поп-класики в культурно-мистецькому просторі сьогодення. Основна увага сконцентрована на аналізі категорії кітчу з суб'єктивних позицій індивіда в умовах його об'єктивації дійсності. Виокремлено мистецьку цінність кітчу в музиці, яка постає у протилежній взаємообумовленості з естетичною. Доведено, що кітч є своєрідним результатом вимог сучасної дійсності, де саме музика є установкою, об'єктивним відображенням дійсності через власний суб'єктивний досвід.

Ключові слова: музика, кітч, суб'єктивний досвід, об'єктивація дійсності, мистецтво.
\end{abstract}

Полюга Виктория Владимировна, кандидат фрилософрских наук, доцент кафредры методики музыкального воспитания и дирижирования, Дрогобычского государственного педагогического университета имени Ивана Франко

Китч в музыке (рецепция опыта и действительности)

Целью исследования является анализ явления китча в музыке с выделением рецептивного характера субъективного опыта индивида в условиях его объективации действительности. Методология исследования основана на феноменологическом методе для объективного изучения проблемы китча в музыке, очерченная субъективным опытом в восприятии, суждении и чувстве, и герменевтический метод, который составляет основу объяснений явления китча в музыке как воспроизведение творческих процессов во внешних проявлениях. Научная новизна заключается в новом ракурсе исследования явления китча не в присущих ему изобразительных формах искусства, а в музыке, и осмысления художественной ценности китча в музыке сквозь призму субъективного опыта индивида и его объективации действительности. Выводы. Осмысленно явление китча и его рецептивный характер с музыкальным жанром поп-классики в культурно-художественном пространстве современности. Основное внимание сконцентрировано на анализе категории китча из субъективных позиций индивида в условиях его объективации действительности. Выделено художественную ценность китча в музыке, которая возникает в противоположной взаимообусловленности с эстетической. Доказано, что китч является своеобразным результатом требований современной действительности, где именно музыка установкой, объективным отражением действительности через собственный субъективный опыт. Ключевые слова: музыка, китч, субъективный опыт, объективация действительности, искусство.

Poliuha Viktoriya, Ph.D.(Philosophy), Associate Professor methods of music education and conducting Drohobych State Pedagogical Ivan Franko University

Kitsch in music (reception of experience and reality)

The purpose of the article is to analyze the phenomenon of kitsch in music with the distinction of the receptive nature of the subjective experience of the individual in the conditions of its objectification of reality. The methodology of the research is based on the phenomenological method for the objective study of the kitsch problem in music, outlined by subjective experience in perception, judgment, and feeling, and the hermeneutic method that forms the basis for explaining the phenomenon of kitsch in music as a reproduction of creative processes in external manifestations. The scientific novelty lies in the new perspective of the study of the phenomenon of kitsch not in the figurative forms of art inherent in him, but in music, and understanding of the artistic value of kitsch in music through the prism of the subjective experience of the individual and his objectification of reality. Conclusions The phenomenon of kitsch and its receptive character with the pop-classic musical genre in the cultural and artistic space of the present are comprehended. The main focus is on analyzing the kitsch category from the subjective positions of the individual in terms of its reality objectification. The artistic value of kitsch in music, which appears in the opposite interdependence with the aesthetic, is singled out. It is proved that kitsch is a peculiar result of the requirements of modern reality, where the music itself is an installation, an objective reflection of reality through its own subjective experience.

Key words: music, kitsch, subjective experience, objectification of reality, art.

Актуальність дослідження. В умовах сучасності кітч став широким феноменом в усіх сферах масової культури. Найбільшого поширення кітч набув у візуалізованих формах відображення, проте кітч як явище не є простим протиставленням високому мистецтву чи мистецтву загалом. Він становить поле, що охоплює естетичні, соціальні, економічні та культурно-мистецькі чинники. Таке трактування провадить до осмислення поняття кітчу як носія мистецької цінності, а саме поціновування кітчу в музиці.

Аналіз останніх досліджень. Теоретичні дослідження кітчу як естетичної категорії та культурного явища лише починають з'являтися в сучасних наукових дослідженнях, та спільною рисою більшості з них є констатація на незавершеності та неповноті осмисленості даної категорії з позицій мистецької цінності чи музичного мистецтва, зокрема. Ольга Муха аналізує смислові трансформації поняття кітчу у 20-21ст., звертаючись до етимологічного аналізу категорії кітчу. Дослідниця констатує на поступовому перетворенні даного поняття від естетичної до загальнокультурної моделі [4].

() Полюга В. В., 2019 
Метою статті $€$ аналіз явища кітчу в музиці крізь призму суб'єктивного досвіду окремого індивіда в умовах його об'єктивації дійсності.

Виклад основного матеріалу. Суб'єкт - це людина, що виступає як автор діяльності, що володіє задумом і засобами реалізації діяльності, зацікавлений у їі результатах і несе за них відповідальність. Поняття суб'єктність дозволяє представити людину не як безпристрасного діячавиконавця, а як упередженого сценариста своїх дій, якому властиві певні переваги, світоглядні позиції й цілеспрямованість перетворювача. Суб'єктність $\epsilon$ найважливішою, сутнісною характеристикою людини і виявляється в спілкуванні, взаємодії і діяльності у вигляді стійких особливостей ії̈ внутрішнього світу, почуттів і ціннісних орієнтацій. Вершиною прояву суб'єктності $є$ чітка життєва позиція людини, у якій знаходить виявлення якість різноманіття відносин людини, простежується рівень досягнень гармонії з самою собою, з навколишнім світом.

Сприймаючи навколишній світ, людині властиво співвідносити все те, що вона бачить, чує, відчуває зі своїм внутрішнім світом, тобто з тим, що вже $є$ в ії особистому досвіді. Тому вирішальним в розумінні суб'єктом нового знання є минулий емоційно-ціннісний, рефрлексивний і когнітивний досвід (тобто суб'єктивний досвід). Індивідуальний досвід людини включає в себе всі ті знання, вміння, навички, яки вона набуває в процесі життєдіяльності. Досвід - це багаж відчуттів, передбачень, очікувань, переживань, осмислення життєвих подій, який стає підґрунтям і мірилом сприйняття навколишнього світу. Залежно від особистого досвіду ми по-різному сприймаємо і відносимося до одних і тих же речей і подій, абсолютно по-різному їх інтерпретуємо. Постає проблема об'єктивної дійсності або об'єктивація дійсності людиною (суб'єктом).

Важливість досвіду як результату чуттєво-емпіричного і теоретичного віддзеркалення світу, як результату різних взаємодій суб'єкта із зовнішнім світом, що ведуть до вироблення уявлень, поглядів, ідей, цінностей, є важливою в умовах сьогодення, оскільки, одна з основних характеристик досвіду, така як формування уявлень, світогляду, цінностей становить його духовну спрямованість, що проявляється в людини в її вищих стремліннях до знання й служіння іншим людям.

Духовність - форма людської самосвідомості, самоідентифікації, основа конструювання людини в ролі суб'єкта відносин, сфера сутності людини [1, 58]. Щодо осмислення даної тематики важливим є звернення до теорії грузинського філософа, психолога Дімітрі Узнадзе (1886-1950). Об'єктивацією Д.Узнадзе називає специфічний акт, який на основі діяльності людини перетворює предмет або явище на спеціальний самостійний об'єкт спостереження. При цьому об'єктивація не створює об'єкти - вони існують в об'єктивній дійсності незалежно від наших актів. "Об'єктивація перетворює наявні об'єкти у предмети, на яких людина концентрує свою увагу, або, точніше кажучи, об'єктивує ї” $[5,65]$. Термін "об'єктивація" науковець вживає у своєрідному значенні : не як перехід внутрішнього у зовнішнє, із суб'єкта в об'єкт, а як результат цього процесу, як створення об'єкта, з яким взаємодіє людина. Виділення об'єкта з кола первинних сприймань на основі установки і $є$ актом уваги. Установка, за Д.Узнадзе, включаючи акт об'єктивації, опредметнює об'єктивний світ. Той чи інший рівень установки філософо вважає специфічним для будь-якої живої істоти. При цьому “Психічний рівень об'єктивації притаманний людині як істоті, що мислить, будує основи культурного життя та виступає творцем культурних цінностей" [5, 120].

Звідси, установка (за Д. Узнадзе) - це весь наш досвід, яким ми не оперуємо цілеспрямовано, а використовуємо автоматично. Якщо ви побачили свого друга десь на вулиці, це вже запускає в вас той чи інший стереотип поведінки і сприйняття просто тому що у вас $є$ попередній досвід спілкування 3 цією людиною. Якщо лікар говорить вам прийняти ті чи інші ліки ви приймаєте їх, тому що довіряєте йому, оскільки, відповідно до вашими переконаннями, лікар - це людина, яка знає і вміє вилікувати. А у когось такою людиною є, для прикладу, ворожка, що і визначає його подальшу поведінку. Установка - це цілісний недиференційований стан, який не тільки передбачає свідому діяльність, але також i зумовлює їі. За висновком Д. Узнадзе "психічна діяльність вторинна по відношенню до установки" [5, 368]. В кожний даний момент у психіку діючого в певних умовах суб'єкта входить з навколишнього середовища і переживається ним з достатньою ясністю лише те, що має місце в річищі його актуальної установки (об'єктивації дійсності). Це означає, що “те, чого не може зробити увага, що мислиться як формальна сила, стає функцією установки, яка виявляється, таким чином, не тільки формальним, а й чисто змістовим поняттям" [5, 368].

3 поданих позицій, осмисливши основоположні виміри інтерактивного характеру суб'єктивного досвіду та об“єктивації дійсності намагатимемось зрозуміти проблеми кітчу з позицій і перспектив фрілософіії, а не історії мистецтва. Тобто нас цікавить, чи ми можемо говорити про кітч чіткими концептуальними категоріями, когнітивними категоріями, які би допомогли нам пояснити реальність, об'єктивну дійсність краще. Проте, підступившись до кітчу, розуміємо, що це дуже складне явище.

Кітч $є$ одним із базових інструментів спрощення реальності, пояснення якої намагаються передати у вигляді якихось стереотипних образів або знаків.

Поняття кітчу зародилося у др. пол. XIX ст. у середовищі мюнхенських арт-дилерів. Його появу пов'язують із запровадженням індустріального виробництва, ростом торгівлі, урбанізацією, виникненням масової культури. 
У культурі та літературі постмодернізму (протягом XX ст.) кітч набув іронічного змісту, при цьому з'явилися такі його означення “пом'якшений”, “іронічний”. Як естетична категорія він пов'язаний із сентименталізмом та мелодрамою, а також мистецтвом, що виглядає дешевим і претензійним. Кітч також асоціюється з об'єктами з високим рівнем емоційної реакції. Європейський фрілософ Томас Кулка визначив три необхідні умови для кітчу: змальовування об'єктів або тем із високою емоційною зарядженістю; об'єкти чи теми постійні та ідентифікуються без зусиль; суттєво не збагачує асоціації, пов'язані зі змальовуваними об'єктами або темами [3]. В сучасному світі кітч легітимізується на рівні освітніх установ, на рівні шкіл, технікумів. І звідси глобальне поширення кітчу.

Кітч часто осмислюють як носія естетичної краси а не мистецької цінності. "Споживач кітчу дивиться на символ, точніше, на те, що символ підміняє” [7, 80]. Кітч апелює передусім до цього емоційного переживання, яке виявляє спонтанні і неопосередковані емоційні референції. Кітч означає тільки те, що він зоображує. Конвенціональність кітчу провадить до того, що кітч не потребує інтерпретації актів. Він дає готові стандартні відповіді. Кітч - породження нового часу. Саме уявлення про кітч формується й поширюється в період модерності. Феномен кітчу не піддається однозначній і послідовній дефініції. Визначення кітчу коливається від цільового негативного впливу до його обґрунтування як естетичного феномену. Поняття масової культури, що передбачає кітч, зазвичай розглядається через принципи деестетизації, які активно розгортаються в модернізмі. Деестетизація художнього явища обумовлена двома чинниками: по-перше, кітч стає як мистецька річ посеред інших речей. По-друге, мистецький твір є продуктом взаємодії соціальних процесів, певної рецепції, сприйняття тексту самоспогляданням самого реціпієнта.

Кітч набагато легше ідентифікувати у візуальних практиках але не в музиці, котра належить до абстрактного виду мистецтва, вона є “Надмистецтвом" (Ф.Ніцше), мистецтвом яке неопосередковано впливає на глибинні смисли людської природи. У дослідженні музики як екзистенційної цінності В. Полюга виокремлює аспект сутністно-особистістного буття, яке вкладено в музиці “Музика - це образ найглибшої сутності світу. Музика справді вказує нам про сутність світу, про сутність нашої особистості, вона ще й виправдовує цю сутність. Адже недоступність, яку неможливо передати словами, може передати тільки музика" [8, 158]. Музика з погляду фрілософських позицій “слугувала своєрідною зоною перетину теоретичних позицій щодо тотожності людського, сутнісного, музичного, особистісного та філософського" [6, 234]. Саме тому поціновування кітчу, в контексті осмислення музики відбувається за його легкість сприйняття. Зауважимо, стосовно трактування кітчу лише як естетичного феномену, а не носія мистецької цінності. Інформативний прогрес та інформаційний простір спонукає соціальні спільноти до життя в заданому темпі в певних просторових характиристиках та часових рамках і з вихідною кінцевою результативністю і саме кітч $€$ своєрідним результатом вимог сучасної дійсності, де музика є установкою, об'єктивним відображенням дійсності через власний суб'єктивний досвід. 3 огляду на це, виникає така думка: Чи можливо, за посередництвом музики, впливати на підсвідомість? I який це має ціннісний зміст, з огляду осмислення кітчу?

Тут варто звернутись до фрейдівської концепції підсвідомого (відображення спогадів або травм дитинства), лібідо (сексуальний потяг як вплив і засіб оперування), або ж 25 кадр як текстове повідомлення, що подається через засоби масової інформації з метою досягти цілі через задіяння підсвідомості (найчастіше використовується в маркетингових цілях). Важливе уточнення, щодо використання лібідо і кітчу. Уявимо собі популярні в сьогоденні банери чи інформативні пости соціальних мереж, де, для прикладу, зоображено автівку і жінку. В таких рекламних конфігураціях кітч використовують як “прозорий символ”. Є товарний знак автівки і символ - гарна жінка, яка спонукає до підсвідомого лібідо. Проте, сама по собі жінка на такому зоображенні не є цінністю, вона повинна лише поєднати бажання, інтерес за посередництвом своєї привабливості і заданий логотип автівки. Тому в зоображенні символ не має естетичного інтересу, а значить сама по собі жінка не є кітчем. 3 точки зору маркетингу, має бути потреба використати товарний знак як мистецький твір, а не як щось, що веде до чогось іншого, прихованого. Як це зробити? Кітч і музика. За зразок, використовують фонову музику у зразках світової поп-класики.

Скажімо якщо при перегляді даного зоображення звучатиме класична музика (Р. Вагнер “Політ валькірій”, Ф. Менельсон "Весільний марш”), яка увійшла в історію як приклад високого мистецтва, заданий зміст носитиме якісно новий характер, оскільки музична класика жила виключно в елітарних колах. ІІї завжди характеризують як таку, що дійсно заслуговує на увагу, класична музика розвиває естетичні смаки, налаштовує та спонукає до серйозного сприйняття. Отже, класична музична фактура з її смисловим навантаженням у кітчі стає легкою розважальною, але одночасно ціннісною, витонченою, якісно-мотивуючою до певних рішень чи дій. Ще раз зазначимо, що акцентуємо увагу на класичній музиці. Поп-класика так само залишається елітарною і в сьогоденні, але ця елітарність вже не є закритою. Навпаки, вона шукає свою аудиторію та прагне ії̈ розширити. Саме тому, з використанням музичного фону у зразку класичної музики візуальний кітч набуває зовсім інших ціннісних суб'єктивних характеристик. Саме в кітчі зародилась нова фрорма взаємодії із музикою. I такий діалог для поп-класики став дуже виграшним. Якщо ти поціновувач бренду ти не можеш не бути поціновувачем класики. Класична музика надає якісно іншу тенденію перетворення змістовного навантаження. “Символ - Знак” трансформується з підсвідомої зверненості на знак, через символічне 
лібідо, на естетично-забарвлений з високою орієнтаційно-ціннісною характеристикою смисловий музичний зразок класики.

Діалектичний закон “єдності і боротьби протилежностей” в такому контексті займає центральне місце, адже саме в кітчі відбувається взаємообумовленість протилежностей (наявність існування однієї протилежності передбачає навність іншої протилежності: якісний-не якісний, високий-низький, вагомий-примітивний). Саме перехід із зміщенням акценту однієї протилежності в іншу шляхом запереченням одна одної одночасно їх взаємопоєднують. Мистецька цінність постає у протилежній взаємообумовленості з естетичною і саме така протилежно зумовлена взаємодія присутня в явищі кітчу. Музичний засіб впливу може здійснюватись через музичний фон як певне тло для досягнення заданої мети. Саме поп-класична музика в контексті такого використання, з властивою для класики академічністю, гармонійністю і чіткою композицією пробиває особистісне звукове поле своєю оркестровою, вокальною, хоровою чи іншою динамікою.

Музичний фон насичує особистісний простір і часто використовується в маркетингових цілях для підсилення емоційного забарвлення, що $є$ ознакою кітчу. Такі засоби наявні в кіноіндустрії, рекламі, в певних видах мотивації до заданої дії (супроводження масових заходів), заклик до здійснення вибору (відпочинкові комплекси), підвищення продуктивності або попиту та інше.

Так, надмірність тиражування музичних шедеврів теж $€$ певним механізмом кітчу. "Аве Марія" Ф.Шуберта чи “Політ Валькірій” Р.Вагнера через надмірну повторюваність стали належати до творів музичного кітчу.

Мінімалізм в музиці визнано ще одним елементом прояву кітчу в музиці.

Ми бачимо, що поп-класична музика здатна змінювати внутрішню конфігурацію та підлаштовуватись під запити суспільства, при цьому не втрачаючи своєї природи. В такому контексті, зважаючи на успіх оркестрів та інструментальних тандемів, можна сподіватись, що, опанувавши нове поле для контакту із сучасним слухачем, класична музика підкорить набагато більше сердець.

Висновки. Якщо коротко узагальнити, то бачимо, що сучасні уявлення про музичне мистецтво з'явилися нещодавно і вони є такими: присутність суб'єктивного досвіду в об'єктивній дійсності; усвідомлення важливості якості твору (який створюється генієм); ця якість не завжди залежить від форми; цьому неможливо навчитись в академії, це щось, що залежить від духу, бо це оригінальний і суб'єктивний досвід, відповідно; цей досвід вчить чомусь новому, він не надто спирається на почуття, більше на мислення; предмет відображення не впливає на велич музичного твору.

Осмислення явища кітчу з музичним жанром поп-класики в культурно-мистецькому просторі сьогодення виходить з суб'єктивних позицій індивіда в умовах його об'єктивації дійсності, а виокремлення мистецької цінності кітчу в музиці $є$ своєрідним результатом, де саме музика є установкою, об'єктивним відображенням дійсності через власний суб'єктивний досвід. Музика не повинна нічого робити, воно просто $є$, а музичне мистецтво відображає дух часу і явище кітчу є незмінним його атрибутом.

\section{תimepamypa}

1. Барулин В.С. Социально-филосовская антропология: Общие начала социально-философской антропологи. Москва : 1994. 256 с.

2. Боришевський М. Й. Духовні цінності як детермінанта розвитку й саморозвитку особистості. Педагогіка і психологія. Київ, 2008. №2 (59). С. 49-57.

3. Бушанський В. В. Кітч. Енциклопедія сучасної України. URL: http://esu.com.ua/search_articles.php?id=7117 (дата звернення: 25.02.2019).

4. Муха О. Кітч: смислові трансформації поняття у XX-XXIст. Наукові записки (Серія “Філософрія"). Національного педагогічного університету імені М. П. Драгоманова, 2012. Вип.12. С. 250-261.

5. Узнадзе Д. Н. Общая психология. Москва : Смысл, 2004. 413с.

6. Полюга В. Музика і фрілософія: “філософія музики" та "музика фрілософііі”. Хорове мистецтво України та його подвижники : матеріали VI Міжнародної науково-практичної, інтернет-конференції (Дрогобич, 19-20 жовтня). Дрогобич, 2017. C.234-247. URL: http://dspu.edu.ua/wp-content/uploads/2016/02/xorove-mystectvo-urayiny-ta-jogo-podvyzhnyky-2017.pdf (дата звернення: 25.02.2019)

7. Kulka, Tomas. Kitsch and art. Pennsylvania State University Press. 1996. November, 27. 168p.

8. Poliuha V. Existential Value of Musical Creativity (Characteristics and Semantic Orientation). Lubelski rocznik pedagogiczny. Lubliń, 2018. Vol. XXXVII. z.2. Pp.153-162. URL: http://journals.umcs.pl//rp/issue/view/492/showToc (дата звернення: 25.02.2019)

\section{References}

1. Barulin, B. C. (1994). Social-Philosophic anthropology: General beginnings of social-philosophical anthropology. Moscow [in Russian]

2. Boryshevsky, M. Y. (2008). Spiritual values as a determinant of development and self-development of personality. Pedagogy and psychology. Kyiv, 2008., 2 (59), 49-57 [in Ukrainian].

3. Bushansky, V. V. Kitsch. Encyclopedia of modern Ukraine. URL: http://esu.com.ua/search_articles.php?id=7117 (application date: 02.25.2019) [in Ukrainian].

4. Mucha, O. (2012). Kitsch: semantic transformation of the concept in the XX-XXIct. Scientific Notes (Series "Philosophy"). National Pedagogical University named after M.P. Dragomanov, 12, 250-261 [in Ukrainian].

5. Uznadze, D. N. (2004). General psychology. Moscow: Smysl [in Russian].

6. Poliuha, V. (2017). Music and Philosophy: "Philosophy of Music" and "Music of Philosophy". Choral Art of Ukraine and its ascetics: materials of the VI International Scientific-Practical, Internet Conference (Drohobych, October 19-20). Drohobych, Pp. 234-247 